\title{
Salvia carreyesii, Salvia ibugana and Salvia ramirezii (Lamiaceae), three new species from Jalisco, Mexico
}

\section{Salvia carreyesii, Salvia ibugana y Salvia ramirezii (Lamiaceae), tres nuevas especies de Jalisco, México}

\author{
Jesús Guadalupe González-Gallegos ${ }^{1 凶}$, José Antonio Vázquez-García ${ }^{1}$ and Miguel de Jesús Cházaro-Basáñez ${ }^{2}$ \\ ${ }^{1}$ Herbario Instituto de Botánica (IBUG), Luz María Villarreal de Puga, Departamento de Botánica y Zoología, Universidad de Guadalajara-CUCBA, \\ Km 15.5 carretera Guadalajara-Nogales, Las Agujas, 45110 Zapopan, Jalisco, México. \\ ${ }^{2}$ Laboratorio de Biogeografia, Departamento de Geografia y Ordenamiento Territorial, Universidad de Guadalajara-CUCSH, Av. Maestros y Mariano \\ Bárcenas, 45101 Guadalajara, Jalisco, México. \\ \xanergo@hotmail.com
}

\begin{abstract}
Three new species from Jalisco, Mexico, are described and illustrated. These species grow in tropical or in tropical and temperate transitional forests. The 3 species belong to Salvia L. subgenus Calosphace (Benth.) Benth. Salvia carreyesii J. G. González is morphologically similar with section Briquetia Epling. It is characterized by the contrasting vegetative morphology between mature and immature individuals, its relatively large and sessile or sub-sessile leaves (the uppermost amplexicaul), glandular-capitate hairs on the floral axis and calyx, and dark violet corollas. The characters of Salvia ibugana J. G. González correspond to those of the species of section Angulatae (Epling) Epling, within which S. ibugana is distinguished by the digitiform papillae disperse on its stems, petioles and floral axis. Salvia ramirezii J. G. González fits well within section Sigmoideae Epling by means of the sigmoid shape of the lower branch of its style. It is morphologically similar to Salvia crucis and S. quercetorum, from which it can be distinguished by the triangular, slightly succulent, shorter, glabrous, lustrous leaves.
\end{abstract}

Key words: digitiform papillae, endemic, Jalisco, section Angulatae, section Briquetia, section Sigmoideae, Salvia subgenus Calosphace.

Resumen. Se describen e ilustran 3 especies nuevas de Jalisco, México. Estas especies crecen en bosques tropicales o en bosques transicionales entre tropicales y templados. Las 3 especies pertenecen a Salvia L. subgénero Calosphace (Benth.) Benth. Salvia carreyesii J. G. González es morfológicamente similar a la sección Briquetia Epling. Se caracteriza por la morfología vegetativa contrastante entre individuos maduros e inmaduros, sus hojas relativamente grandes, sésiles o subsésiles (las superiores amplexicaules), tricomas capitado-glandulares sobre el eje floral y el cáliz, y corolas violeta oscuro. Las características de Salvia ibugana J. G. González corresponden a aquellas de las especies de la sección Angulatae (Epling) Epling, dentro de la que S. ibugana se distingue por las papilas digitiformes que presenta en el tallo, peciolo y eje floral. Salvia ramirezii J. G. González se ubica bien dentro de la sección Sigmoideae Epling debido a la forma sigmoide de la rama inferior del estilo. Es morfológicamente similar a Salvia crucis Epling y S. quercetorum Epling, de las que se distingue principalmente por las hojas triangulares, ligeramente suculentas, más cortas, glabras y lustrosas.

Palabras clave: papilas digitiformes, endémico, Jalisco, sección Angulatae, sección Briquetia, sección Sigmoideae, Salvia subgénero Calosphace.

\section{Introduction}

A revision of the Lamiaceae family in the state of Jalisco (western Mexico) as part of the project "Flora de Jalisco y Áreas Colindantes", allowed us to uncover 3 distinct populations of Salvia that were not referable to any of the previously described species in the genus. We therefore describe 3 new species, one related to section

Recibido: 23 diciembre 2011; aceptado: 22 myao 2012
Briquetia Epling, and the others belonging to sections Angulatae (Epling) Epling and Sigmoideae Epling, respectively, according to the classification proposed by Epling and coworkers (Epling, 1940, 1941, 1944, 1947, 1951; Epling and Mathias, 1957; Epling, 1960; Epling and Játiva, 1963, 1966, 1968).

Specimens of the new species were collected and recorded their morphological variability, distribution and habitat requirements. From January to March 2011, some individuals of each species were dug up and cultivated 
at the botanical garden of the Instituto de Botánica, Universidad de Guadalajara, Zapopan, Jalisco.

\section{Descriptions}

Salvia carreyesii J. G. González sp. nov. Type: Mexico. Jalisco. Municipio de Puerto Vallarta: La Laja stream, 0.75 km WNW of Las Mesas, 20 $30^{\circ} 39^{\prime \prime} \mathrm{N}, 105^{\circ} 6$ '28” W, 1 100 m, 11 Nov 2009 (fl.), P. Carrillo R., D. Cabrera T. and C. Gallardo 5842 (holotype: IBUG; isotype: IEB). Fig 1.

Salviae sectione Briquetiae aemulans, sed corollarum labio inferior quam superior longior; $S$. mexicanae affinis sed habitu prostrato, petiolis $0-3.5 \mathrm{~mm}$ (vs $1-10 \mathrm{~cm}$ ) longis, foliis juvenilibus dense albo-tomentosis, pedicellis 3-4 $\mathrm{mm}$ (vs 3-20 mm) longis et glandulosis, calycibus 8-9 mm (vs $8-20 \mathrm{~mm}$ ) longis et glandulosis, corollis atroviolaceis (vs atrocaeruleis), filis $2-3 \mathrm{~mm}$ (vs. $4-7 \mathrm{~mm}$ ) longis, connectivis 7-8 mm (vs. 8-30 mm) longis, thecis 2-2.2 mm (vs. 3.6-5 mm) longis, stylis 2-2.2 $\mathrm{mm}(2.8-4 \mathrm{~mm})$ longis notabilis.

Perennial herbs, erect when young and gradually inclined till reach a prostrate habit which roots a the nodes, $30-80 \mathrm{~cm}$ long, stem sparsely puberulent to glabrous in mature individuals (puberulent to densely hirsute with white or often yellow hairs in immature ones), internodes $6-12 \mathrm{~cm}$ long. Petioles $0-3.5 \mathrm{~mm}$ long (the uppermost leaves always sessile), usually glabrous or sometimes puberulent. Leaf blades ovate to broadly oblong-lanceolate, (6-) $11-18 \mathrm{~cm} \times(3-) 6-8.5 \mathrm{~cm}$, green, acuminate at the apex, rounded, slightly cordate or sometimes oblique at the base (the uppermost leaves occasionally amplexicaul), the margin serrate, both surfaces essentially glabrous or sparsely puberulent, and smooth (in immature individuals the leaves are densely covered with erect yellow or white hairs in the adaxial surface, and bullate, the abaxial surface densely covered with whitish-silver appressed hairs). Inflorescences arranged in terminal racemes, (2-)4.5-10.5 $\mathrm{cm}$ long, with 4-9 verticillasters, each verticillaster 6 to 12-flowered, floral axis with erect simple hairs and sparsely shorter glandular capitate ones. Floral bracts deciduous, ovate, (6-)11-18 × (3-)6-8.5 mm, green, glabrous except at the margin which is short and sparsely ciliated, acuminate to cuspidate at the apex, truncate at the base, the margin entire. Pedicels 3-4 mm long, hirtellous and with tiny glandular capitate hairs. Calyces 8-9 × 5-6 mm, not accrescent, green, hirtellous and with glandular capitate hairs on the veins, sparsely covered with conical tiny hairs at the inner surface, upper lip 3-veined, lips equal in length and acute. Corollas dark violet with white nectar guides on the lower lip at the throat, sparsely pilose in the upper lip and in the abaxial surface of the lower one, tube 1.7-1.8 $\times$ 4-5 mm, ventricose, not invaginated, internally naked; upper lip 5-6 mm long, lower one 5-8 $\times 6 \mathrm{~mm}$. Stamens included; filaments 2-3 mm long; connective 7-8 $\mathrm{mm}$ long, not geniculate, not evidently dentate; theca 1-2 mm long; staminodes present, represented by a tiny papilla above and behind the insertion point of each filament to corolla tube. Gynobasic horn 1-1.2 mm long; styles 2-2.2 cm long, slightly sigmoid (the curves follow the shape of the corolla), sparsely pilose at the apex, lower branch acute. Nutlets ovoid, 1.5-1.8 $\times 1-1.3 \mathrm{~mm}$, pale brown marbled with dark brown stains, glabrous and smooth.

Taxonomic summary

Distribution, habitat and phenology. Salvia carreyesii is only known from the dirt road between Puerto Vallarta and El Cuale, near to El Nogalito stream, Jalisco, Mexico (Fig. 2). It inhabits in ecotones between tropical subdeciduous and oak forests from 980 to $1100 \mathrm{~m}$, generally near to perennial watercourses. It shares habitat with Ardisia compressa Kunth, Cecropia obtusifolia Bertol., Croton suberosus Kunth, Hedyosmum mexicanum C. Cordem., Myrica cerifera (L.) Small, Podocarpus reichei J. Buchholz et N. E. Gray, and Euphorbia peritropoides (Millsp.) V. W. Steinm. Salvia carreyesii probably blooms and sets fruits from September to early December.

Etymology. The specific epithet of this plant is a fusion of surnames that honors the first collector: Pablo Carrillo Reyes, long distance runner and photographer by hobby, and botanist by profession, as describes himself; but above all, he is a good friend and an enthusiastic botanist.

Additional material examined. Mexico. Jalisco. Municipio de Puerto Vallarta: Las Lajitas stream, south of Las Mesas, dirt road form Puerto Vallarta to El Cuale, 20 30'36.3” N, 1056'29.7' W, 1049 m, 30 Dec 2010 (ster.), González et al. 798 (IBUG); by a stream on dirt road Puerto Vallarta to El Cuale, ahead of El Nogalito stream, $22 \mathrm{~km}$ from El Remance bridge, $20^{\circ} 31^{\prime} 42.84^{\prime \prime} \mathrm{N}, 105^{\circ} 5^{\prime} 51.32^{\prime \prime} \mathrm{W}, 980$ m, 12 Feb 2011 (ster.), González et al. 871 (IBUG).

Remarks. Salvia carreyesii is not clearly related to any of the sections defined by Epling and co-workers (Epling, 1940, 1941, 1944, 1947, 1951; Epling and Mathias, 1957; Epling, 1960; Epling and Játiva, 1963, 1966, 1968). However, most of the characters exhibited by $S$. carreyesii are shared by the species included in section Briquetia Epling. This section is characterized by wide leaves, rounded to attenuated, sometimes truncate or cordate at the base, lips of the calyces subequal in length, 3-veined upper lips, dark blue corollas, ventricose and mostly invaginated tubes, internally naked, upper corolla lip longer than the lower one, stamens included, connectives with a small ventral tooth or subentire, pilose styles, upper branch of the style longer than the lower one. Nevertheless, there is only one divergent character; the upper lip of the corolla is equal or shorter than the lower one in S. carreyesii. 
Salvia carreyesii is distinctive by the 2 striking different vegetative morphologies between mature and immature plants. Young individuals are erect, possess puberulent to densely hirsute stems, leaves bullate and densely covered with yellow or white hairs above and whitish appressed hairs below. Mature (flowering) individuals are declined and tend to be prostrate, lack of hairs, and the leaves are smooth. Other characters that help to distinguish $S$. carreyesii are the relatively large and sessile or subsessile leaves (the uppermost amplexicaul), glandular-capitate hairs on the floral axis and calyces, and dark violet corollas. The unique member of section Briquetia growing in Jalisco is $S$. mexicana L., which can be distinguished by longer petioles, cuneate to attenuated leaf base, longer floral structures (pedicel, calyx, corolla (the tube and upper lip length), corolla lips, filament, connective, theca and style), and the absence of glandular capitate hairs in pedicel and calyx (Table 1). Furthermore, S. carreyesii has a tendency to grow in more tropical forests and warmer lowlands than S. mexicana.

Key for Salvia mexicana and S. carreyesii

1a. Base of the leaf blades cuneate or long attenuated, petioles $1-10 \mathrm{~cm}$ long; pedicels 3-20 $\mathrm{mm}$ long, moderate to densely covered with eglandular hairs; calyces sparse to densely covered with eglandular hairs; corolla upper lip 13-14(-19) $\mathrm{mm}$ long, lower one 12-17 mm long; filaments 4-7 mm long, connectives 8-30 mm long, thecae 2.8-4 mm long; style 3.6-5 cm long....... S. mexicana 1b. Base of the leaf blades rounded, slightly cordate or sometimes oblique, petioles $0-0.35 \mathrm{~cm}$ long; pedicel 3-4 mm long, covered with glandular capitate hairs; calyces covered with glandular capitate hairs; corolla upper lip 5-6 mm long, lower one 5-8 mm long; filaments 2-3 mm long, connective 7-8 $\mathrm{mm}$ long, thecae 1-2 $\mathrm{mm}$ long; style 2-2.2 $\mathrm{cm}$ long.....

S. carreyesii

Table 1. Character comparison between Salvia mexicana and $S$ carreyesii

\begin{tabular}{|c|c|c|}
\hline Characters & S. mexicana & S. carreyesii \\
\hline \multicolumn{3}{|l|}{ Leaves } \\
\hline Petiole length $(\mathrm{cm})$ & $1-10$ & $0-0.35$ \\
\hline Leaf blade shape & Ovate to ovate-elliptic & Ovate to oblong-lanceolate \\
\hline Leaf blade size $(\mathrm{cm})$ & $6-18(-20) \times 2.5-12$ & $(6-) 11-18 \times(3-) 6-8.5$ \\
\hline Apex shape & Acute or acuminate & Acuminate \\
\hline Base shape & Cuneate to attenuated (rarely subcoradate) & $\begin{array}{c}\text { Rounded, slightly cordate or sometimes } \\
\text { oblique }\end{array}$ \\
\hline \multicolumn{3}{|l|}{ Inflorescence } \\
\hline Flowers per verticillaster & 10 to 12 & 6 to 12 \\
\hline \multicolumn{3}{|l|}{ Floral bract } \\
\hline Shape & Ovate & Ovate \\
\hline Size $\mathrm{mm}$ & $6-12(-20) \times 3-5$ & $(6-) 11-18 \times(3-) 6-8.5$ \\
\hline \multicolumn{3}{|l|}{ Pedicel } \\
\hline Length (mm) & $3-20$ & $3-4$ \\
\hline Glandular capitates hairs & Absent & Present \\
\hline \multicolumn{3}{|l|}{ Calyx } \\
\hline Length (mm) & $8-17(-20)$ & $8-9$ \\
\hline Glandular capitates hairs & Absent & Present \\
\hline \multicolumn{3}{|l|}{ Corolla } \\
\hline Color & Dark blue & Dark violet \\
\hline Tube length (mm) & $15-25$ & $17-18$ \\
\hline Upper corolla lip length (mm) & $13-14(-19)$ & $5-6$ \\
\hline
\end{tabular}


Table 1. Continues

\begin{tabular}{lcc}
\hline Characters & S. mexicana & S. carreyesii \\
\hline Lower corolla lip length $(\mathrm{mm})$ & $12-17$ & $5-8$ \\
Androecium & & $2-3$ \\
Filament length $(\mathrm{mm})$ & $4-7$ & $7-8$ \\
Connective length $(\mathrm{mm})$ & $8-30$ & $1-2$ \\
Theca length $(\mathrm{mm})$ & $2.8-4$ & $2-2.2$ \\
Gynoecium & $3.6-5$ & Ecotones between tropical subdeciduous \\
Style $(\mathrm{cm})$ & and oak forests \\
Vegetation & Pine, pine-oak, oak, montane cloud, and \\
& tropical deciduous forests & Jalisco \\
Geographical range & Mexican Pacific slope from Durango, & $900-1100$ \\
& Zacatecas and San Luis Potosí to Oaxaca & and Puebla \\
Altitudinal range $(\mathrm{m})$ & $(800-) 1000-2900$ &
\end{tabular}

Salvia ibugana J. G. González sp. nov. Type: Mexico. Jalisco. Municipio de Cabo Corrientes: road from Refugio de Suchitán to El Chimo, 20²6'52.49” N, 105³5'11.4” W, 605 m, 13 Mar 2011 (fl., fr.), J. G. González, J. A. Vázquez and E. De Castro. 939 (holotype: IBUG; isotypes: IEB, MEXU, ZEA, ENCB). Fig. 3.

Salviae sectione Angulatae adscribenda, species insignis caulibus, petiolis et axibus inflorescentiarum suis papillatis distincta (papillae habitum lichenis viridis leniter referentia), a speciebus nobis notis bene.

Perennial herb or subshrub, erect, 1.5-2 m tall, stems sparsely puberulent, profusely ornate with digitiform or lichenoid papillae, 1-2 mm long (such papillae also present on petioles and in lesser extent on floral axis). Petioles (1-)4-6(-8.5) cm long, puberulent and sparsely covered with appressed hairs. Leaf blades ovate, 6-12(-15.5) $\times$ 4-7($10.5) \mathrm{cm}$, green, acuminate at the apex, slightly truncate or rounded and then abruptly cuneate at the base, the margin serrate (entire near the base), both surfaces glabrous except for the primary and secondary veins which are covered with tiny appressed hairs, abaxial surface densely covered with glandular dots. Inflorescences arranged in terminal and subterminal racemes, (5-)10-18(-30) cm long, with 18-35 verticillasters, $0.7-1.5 \mathrm{~cm}$ apart towards the base, each verticillaster 10 to 18 -flowered. Floral bracts deciduous, ovate, (1-)1.3-1.5(-2.4) × 1-1.7 mm, green, puberulent, attenuated at the apex, truncate at the base, margin entire, venation not obvious. Linear bracteoles present at the base of each pedicel, 1-2 mm long. Pedicels 1.5-3.1 mm long, covered with short conical hairs. Calyces 3.1-3.8(-5)× (1.7-)2.3-2.5 mm, slightly accrescent, reaching up to $5.2 \times$ $3.3 \mathrm{~mm}$ during fructification, green and bluish towards the apex, puberulent or hispidullous mainly on the veins and internally glabrous, the upper lip 3-veined, lips equal in length, the upper lip and the lobes of the lower one acute. Corolla sky blue with white nectar guides on the lower lip and paler tube towards its base, essentially glabrous except the upper lip which is moderately to densely pilose; tubes $5-5.5 \times 2 \mathrm{~mm}$, ventricose and invaginated, internally naked at the base; upper lip 4-4.5 $\mathrm{mm}$ long, lower one 4-5.6 × 4-5 mm. Stamens included; filaments 1.4-1.5 $\mathrm{mm}$ long; connectives $4.5-5.5 \mathrm{~mm}$ long, with a triangular retrorse tooth at its middle portion; thecae $1-1.3 \mathrm{~mm}$ long; staminodes present above and behind the insertion point of each filament to the corolla tube. Gynobasic horn 1-1.1 mm long, obtuse at the apex; styles 7-9 $\mathrm{mm}$ long, pilose towards the apex, slightly exerted (only the branches). Nutlets ovoid, 1.2-1.3 $\times 0.7-1 \mathrm{~mm}$, pale ocher, concolor, sometimes pilose when immature, with the hairs concentrated towards the junction with the gynophore, smooth and sparsely covered with dark amber and black glandular dots.

\section{Taxonomic summary}

Distribution, habitat and phenology. Salvia ibugana is endemic to Jalisco, Mexico (Fig. 2). It grows in tropical subdeciduous forest or secondary palm grove, from 550 to $600 \mathrm{~m}$. It shares habitat with Begonia jaliscana BurtUtley, Brosimum alicastrum Sw., Calophyllum brasiliense Cambess., Cecropia obtusifolia, Clusia salvinii Donn. Sm., Cryosophila nana (Kunth) Blume, Dalechampia scandens L., Hura polyandra Baill., Ipomoea neei (Spreng.) O'Donell, Orbignya guacuyule (Liebm. ex Mart.) Hern.Xol., Oreopanax peltatus Linden, Piper hispidum Kunth, Ardisia sp., Miconia sp., Peperomia sp., Russelia sp. and Bursera spp. This species blooms and fructifies from middle February to March. 
Etymology. Salvia ibugana is named after the acronym of Herbario Luz María Villarreal de Puga del Instituto de Botánica (IBUG), Universidad de Guadalajara, Mexico. This Institution has been conducive to the formation of new botanists and to increase the knowledge and documentation of the flora of western Mexico.

Additional material examined. Mexico. Jalisco. Municipio de Cabo Corrientes: road down from La Pitarilla, between Guázima and Agua Caliente, $20^{\circ} 27^{\prime} 10^{\prime \prime} \mathrm{N}, 105^{\circ} 34^{\prime} 30^{\prime \prime} \mathrm{W}$, 550 m, 2 Mar 1993 (fl.), Castillo et al. 10630 (XAL); road Refugio de Suchitán-Chimo, 20²7'2.8” N, 105³5'24.2" W, 560-600 m, 19 Feb 1998 (fr.), Ramírez et al. 5076 (IBUG). Municipio de Puerto Vallarta: Las Guacas, 600 m, 22 Feb 1998 (fl.), Ramírez et al. 5239 (IBUG); Las Guacas (San Sebastián del Oeste), 5 Mar 2000, Villarreal 17782 (IBUG-2 sheets).

Remarks. Salvia ibugana is well enclosed into the definition of section Angulatae (Epling) Epling. However, it is worth to highlight that this section is one of the richest and most complicated defined by Epling within the subgenus Calosphace (1939, 1940, 1941, 1963). He included 48 species, most of them difficult to delineate and several probably will prove to be conspecific. The characters shared by these species, which define the section, are: ovate, elliptic or sometimes deltoid-ovate leaves, cuneate to long attenuated at base or sometimes rounded and abruptly and shortly cuneate, 3-veined upper lip of the calyx, white or sky blue corolla, ventricose tube, internally naked, lower corolla lip longer than the upper one, stamens included, connective with a retrorse tooth in the middle, pubescent or rarely glabrous style. A relevant factor that is hard to deal with is the relatively broad geographical range of this group. They spread from northern Mexico to northern Argentina through the Andean Mountain Range, and southern Brazil. This can partially explain the absence of a recent taxonomic treatment particularly for this section. Fortunately, $S$. ibugana is strikingly different in having the digitiform or lichenoid papillae throughout its stems, petioles and floral axis, and bracteoles present together with the typical floral bracts. These characters clearly differentiate it from its closest similar species, $S$. longispicata M. Martens and Galeotti and S. roscida Fernald (Table 2). The green papillae that characterize this species are unique in the genus.

The habit and general aspect of this new taxon resemble those of what we consider as the S. roscida complex, which includes the formerly valid species $S$. fallax Fernald, $S$. muscidiflora Fernald, S. remissa Epling, and S. roscida. In the local area this complex occupies mainly temperate habitats like pine-oak, oak and cloud montane forests. It is highly probable that $S$. ibugana has diverged from the core of this complex by means of the pressure of warmer and wetter environments.

Salvia ibugana was collected near S. ramirezii at Las Guacas zone in Puerto Vallarta Municipality by R. Ramírez Delgadillo et al. 5239 (Feb. 1998). However, we could not find any of them in such locality during 2 different expeditions (22 Oct 2010 and 11 Feb 2011). No other sage has been observed growing together with S. ibugana.

Key for Salvia ibugana and morphologically similar taxa

1a. Papillae digitiform or lichenoid present in the stems, petioles and floral axis; floral bract always deciduous and bracteoles present; calyces 3.1-3.8(-5) mm long; corolla tubes 5-5.5 mm long...... S. ibugana 1b. Papillae absent throughout the plant surface; floral bracts deciduous or persistent and bracteoles absent; calyces 4-7(-9) mm long; corolla tubes 6-9.7 mm long

2a. Verticillasters 10 to 24 -flowered; floral bracts generally deciduous S. longispicata

2b. Verticillasters 4 to 12 -flowered; floral bracts always persistent. S. roscida

Table 2. Character comparison between Salvia ibugana and morphologically most similar taxa

\begin{tabular}{lccc}
\hline Characters & S. longispicata & S. roscida & S. ibugana \\
\hline $\begin{array}{l}\text { Digitiform or lichenoid } \\
\text { papillae }\end{array}$ & Absent & Absent & $\begin{array}{c}\text { Present in the stems, petioles and } \\
\text { floral axis }\end{array}$ \\
$\begin{array}{l}\text { Leaves } \\
\text { Petiole length }(\mathrm{cm})\end{array}$ & $3-5$ & $1-4(-7)$ & $(1-) 4-6(-8.5)$ \\
Leaf blade shape & Ovate to ovate-lanceolate & Ovate & Ovate \\
Leaf blade size $(\mathrm{cm})$ & $4-7(-10) \times 2.5-4(-6.5)$ & $7.5-12 \times 5-6$ & $6-12(-15.5) \times 4-7(-10.5)$ \\
Apex shape & Long acute & Acute to acuminate & Acuminate \\
Base shape & Cuneate to attenuated & Cuneate & $\begin{array}{c}\text { Slightly truncate to rounded and } \\
\text { then abruptly cuneate }\end{array}$
\end{tabular}


Table 2. Continues

\begin{tabular}{|c|c|c|c|}
\hline Characters & S. longispicata & S. roscida & S. ibugana \\
\hline Margin shape & Serrate & Serrate & Serrate \\
\hline \multicolumn{4}{|l|}{ Inflorescence } \\
\hline Flowers per verticillaster & 10 to 24 & (4-)8 to 12 & 10 to 18 \\
\hline \multicolumn{4}{|l|}{ Floral bract } \\
\hline Shape & Ovate to ovate-lanceolate & $\begin{array}{l}\text { Triangular, ovate or } \\
\text { narrow lanceolate }\end{array}$ & Ovate \\
\hline Size $(\mathrm{mm})$ & $\begin{array}{c}(1.7-) 2-3(-6.8) \times 0.5-1.2(- \\
3.7)\end{array}$ & $1.1-2.6 \times 1-2$ & $(1-) 1.3-1.5(-2.4) \times 1-1.7$ \\
\hline \multicolumn{4}{|l|}{ Pedicel } \\
\hline Length (mm) & $1.5-2.3$ & $2-3$ & $1.5-3.1$ \\
\hline \multicolumn{4}{|l|}{ Calyx } \\
\hline Length (mm) & $5-7(-9)$ & $4-5.5$ & $3.1-3.8(-5)$ \\
\hline \multicolumn{4}{|l|}{ Corolla } \\
\hline Color & $\begin{array}{c}\text { Sky blue to dark blue } \\
\text { with white macules at the } \\
\text { throat }\end{array}$ & $\begin{array}{l}\text { Sky blue with white } \\
\text { macules at the throat }\end{array}$ & $\begin{array}{l}\text { Sky blue with white macules at the } \\
\text { throat }\end{array}$ \\
\hline Tube length (mm) & $6-7(-9.7)$ & $(6.8-) 7-8$ & $5-5.5$ \\
\hline Upper lip length (mm) & $4-5.5$ & $4-5$ & $4-4.5$ \\
\hline Lower lip length (mm) & $5-6.5$ & $5.2-7$ & $4-5.6$ \\
\hline \multicolumn{4}{|l|}{ Androecium } \\
\hline Filament length (mm) & $1.2-1.6(-2)$ & $1.2-1.5$ & $1.4-1.5$ \\
\hline Connective length (mm) & $4.5-5(-9)$ & $4-5$ & $4.5-5.5$ \\
\hline Theca length (mm) & $1.1-1.3$ & $1-1.3$ & $1-1.3$ \\
\hline \multicolumn{4}{|l|}{ Gynoecium } \\
\hline Style length (mm) & $9-10$ & $8-9$ & $7-9$ \\
\hline \multicolumn{4}{|l|}{ Nutlet } \\
\hline Length (mm) & $1.1-1.2 \times 0.7-0.8$ & $1-1.1 \times 0.6$ & $1.2-1.3 \times 0.7-1$ \\
\hline Vegetation & $\begin{array}{c}\text { Tropical deciduous, } \\
\text { secondary vegetation of } \\
\text { pine-oak and pine forests, } \\
\text { and subtropical shrub }\end{array}$ & $\begin{array}{c}\text { Pine-oak, oak, } \\
\text { montane cloud and } \\
\text { tropical subdeciduous } \\
\text { forests }\end{array}$ & $\begin{array}{l}\text { Tropical subdeciduous forests and } \\
\text { secondary palm grove }\end{array}$ \\
\hline Geographical range & $\begin{array}{l}\text { Almost all the Mexican } \\
\text { states except for those } \\
\text { from the California and } \\
\text { Yucatán Peninsulas }\end{array}$ & $\begin{array}{l}\text { Sinaloa, Durango, } \\
\text { Nayarit, Jalisco, } \\
\text { Michoacán, Guerrero } \\
\text { and Oaxaca }\end{array}$ & $\begin{array}{l}\text { Along the cost of Bahía de } \\
\text { Banderas, Jalisco }\end{array}$ \\
\hline Altitudinal range $(\mathrm{m})$ & $400-200(-3050)$ & $\begin{array}{l}(600-) 1000-1950(-2 \\
637)\end{array}$ & $550-600$ \\
\hline
\end{tabular}

Salvia ramirezii J. G. González sp. nov. Type: Mexico, Jalisco. Municipio de Mascota: by El Cabro hill, 9.7-9.9 km SW of San Juan del Mosco on dirt road to Puerto Vallarta, Los Sauces y Agujes, 20³1'37.2” N, 10457'9.2” W, 1628 m, 21 Jul 2011 (fl., fr.), J. G. González-G., A. Castro-C., R.
Guerrero-H., I. Guerrero and C. Beltrán 1042 (holotype: IBUG; isotypes: IEB, MEXU, ZEA, XAL). Fig. 4.

Salviae sectione Sigmoideae adscribenda, a $S$. quercetorum et $S$. crucis foliis sessilibus, brevioribus (6-23 $\times$ 5-8 $\mathrm{mm}$ vs. $9-30(-55) \times(6-) 12-22 \mathrm{~mm})$, triangularibus, 
triangulo-lanceolatis vel lanceolatis, floribus 2 in verticillastris (vs. 2-12) differt.

Perennial herbs up to $1 \mathrm{~m}$ tall; stems emerging from a subterranean cylindrical tuber, highly branched, markedly quadrangular, sparsely pilose and sometimes farinaceous between the ribs and in the junction of the petioles and between them (particularly on the young branches and on the floral axis), sparsely ornate with orange or ocher glandular dots (invisible to the naked eye). Leaves subsessile or with petioles $0.3-1(-3.8) \mathrm{mm}$ long; leaf blades triangular, triangular-lanceolate to lanceolate, (6-)9.4$15(-23) \times(2.2-) 5-13.3 \mathrm{~mm}$, often slightly succulent, acuminate to acute at apex, slightly cordate at base, the margin entire or sparsely crenate, short revolute when dried, adaxial surface green, smooth and usually lustrous, abaxial surface paler and densely glandular punctate and sometimes densely farinaceous (then the secondary veins hidden by the granules), the glands ocher or dark orange. Inflorescence arranged in terminal and subterminal lax racemes, (2-)10-20 cm long, each floral axis with (5-)1027 verticillasters, these 2-flowered, floral nodes 5-15 $\mathrm{mm}$ apart towards the base. Floral bracts late deciduous, lanceolate to ovate-lanceolate, $(1.7-) 2-2.5 \times 0.5-1 \mathrm{~mm}$, acute at the apex, truncate at the base, the margin entire, green, glabrous except the margin which is sometimes covered with erect short hairs (there are erect hairs also at the junction between the bract and the floral axis), densely glandular punctate and sometimes farinaceous, the glands dark orange or ocher. Pedicels 1-2(-3) mm long, densely covered with short conical hairs and farinaceous. Calyx $3-5 \times 2-3.5 \mathrm{~mm}$, poorly accrescent, it reaches $5-6 \times 4-5$ $\mathrm{mm}$, green, heavily covered with dark orange or ocher glandular dots, essentially glabrous with short erect hairs on the margin of the lips, farinaceous, the upper lip 5 or 7 -veined, lips acute and subequal in length. Corollas blue with white nectar guides, densely pilose and ornate with dark orange sessile glands toward the throat, tube (3-)5-6 $\times 2 \mathrm{~mm}$, slightly ventricose and invaginated at the base, internally ornate with 2 ventral folds; upper lip (3-)4-5 $\mathrm{mm}$ long, lower lip 4-5 × 6.4-6.6 mm. Stamens included; filaments 1-1.5 mm long; connectives $1.8-2.5 \mathrm{~mm}$ long, geniculate; thecae (7-)1-1.3 mm long; staminodes present above and behind the insertion point of each filament to the corolla tube, globose at the apex. Gynobasic horn $1 \mathrm{~mm}$ long; styles 7-8 mm long, pilose, included except the style branches, the lower branch sigmoid. Nutlets ovoid, 1.5-2 $\times 1-1.3 \mathrm{~mm}$, grayish-brown and dark-brown marbled, glabrous and smooth.

Taxonomic summary

Distribution, habitat and phenology. Salvia ramirezii is endemic to Jalisco, Mexico (Fig. 2). It inhabits tropical deciduous forests or ecotones of this vegetation with oak or oak-pine forests, from $600-1640 \mathrm{~m}$. It grows together with Brosimum alicastrum, Cecropia obtusifolia, Clusia salvinii, Cryosophila nana, Euphorbia calcarata (Schltdl.) V. W. Steinm., Hura polyandra, Pinus oocarpa Schiede ex Schltdl., Quercus glaucescens Humb. and Bonpl., $Q$. glaucoides M. Martens and Galeotti, Q. uxoris McVaugh, Orbignya sp., Piper sp., and Ficus sp. This species blooms and fructifies from late July to late April, as evidenced by the specimens collected.

Etymology. Salvia ramirezii is named in honor of Raymundo Ramírez Delgadillo (1968-2011), one of the few people who mastered the knowledge of the flora of Jalisco, Mexico. Dear friend for his students. He contributed greatly to the emergence of a new generation of Mexican botanists.

Additional material examined. Mexico. Jalisco. Municipio deMascota: El Cabro hill, by El Terrero, 31 Jul 2005 (fl., fr.), Cházaro and Ascencio 8521 (XAL); 8.7-8.8 km SW of San José del Mosco on the dirt road to El Cabro-Zapotán, Los Sauces y Agujes, 20³1'32.9” N, 10457'12.3” W, 1640 m, 22 Apr 2011 (fl., fr.), González and Guerrero 1002 (IBUG, IEB); 9.4 km SW of San José del Mosco dirt road to El Cabro-Zapotán, Los Sauces y Agujes, 20³1'39.2” N, 10457'19.3” W, 1638 m, 23 Apr 2011 (fl., fr.), González and Guerrero 1005 (IBUG, MEXU). Municipio de Puerto Vallarta: Las Guacas, 600 m, 22 Feb 1998 (fl., fr.), Ramirez et al. 5212 (IBUG); mountains of Puerto Vallarta towards El Cuale, 23 Sep 2009 (fl., fr.), Romero s.n. (IBUG); Ojo de Agua Ranch, 1 400-1 600 m, 11 Feb 2010 (fl., fr.), Romero 72 (IBUG). Municipio de Talpa de Allende: on road from Talpa de Allende to Tomatlán, $26.2 \mathrm{~km} \mathrm{~S}$ of Talpa, $1440 \mathrm{~m}, 9 \mathrm{Nov}$ 1975 (fl., fr.), Peterson and Broome 428 (IBUG).

Remarks. Salvia ramirezii corresponds undoubtedly to section Sigmoideae Epling because of the sigmoid shape of the lower branch of the style. This character is only present as far as we know in that section. Sigmoideae is endemic to Mexico. According to Espejo and Ramamoorthy (1993), it includes 11 species. They suggest the state of Jalisco as the possible center of diversification and dispersion of this group since 6 of the species grow there; so, the discovery of the new taxon in this Mexican state is not surprising and supports the Espejo and Ramamoorthy's hypothesis. The new species is morphologically similar to $S$. crucis Epling and $S$. quercetorum Epling. It differs from the first one in having evident triangular or narrow lanceolate leaves, generally shorter, sessile or rarely with petioles up to $3.8 \mathrm{~mm}$ long, glabrous, smaller floral bracts, verticillasters always 2 -flowered and shorter lower corolla lips (Table 3). The following characters of S. quercetorum establish the difference from $S$. ramirezii: lanceolate to elliptic-lanceolate leaves, $1.3-7.4 \times 1-1.8 \mathrm{~cm}$, cuneate at the base, margin serrate, petiole up to $2-9 \mathrm{~mm}$ long, 
Table 3. Character comparison between Salvia ramirezii and morphologically similar taxa

\begin{tabular}{|c|c|c|c|}
\hline Characters & S. crucis & S. quercetorum & S. ramirezii \\
\hline \multicolumn{4}{|l|}{ Leaves } \\
\hline Petiole length $(\mathrm{cm})$ & $(0.2-) 1.6-2.3$ & $0.2-0.5(-0.9)$ & $0-0.1(-0.38)$ \\
\hline Leaf blade shape & Ovate to rhombic-deltoid & $\begin{array}{l}\text { Lanceolate to elliptic- } \\
\text { lanceolate }\end{array}$ & $\begin{array}{l}\text { Triangular, triangular-lanceolate to } \\
\text { lanceolate }\end{array}$ \\
\hline Leaf blade size $(\mathrm{cm})$ & $0.9-3(-4.56) \times 0.2-2.5(-3.5)$ & $(1.3-) 3-5(-7.4) \times 1-1.5(-1.8)$ & $\begin{array}{c}(0.6-) 0.94-1.5(-2.3) \times(0.22-) 0.5- \\
1.33\end{array}$ \\
\hline Apex shape & Acute to rounded & Acute & Acuminate to acute \\
\hline Base shape & Truncate to slightly cordate & Cuneate & Slightly cordate \\
\hline Margin shape & Serrate & Serrate & $\begin{array}{l}\text { Entire or sparsely crenate and } \\
\text { shortly revolute }\end{array}$ \\
\hline Pubescence & Present & Absent & Absent \\
\hline \multicolumn{4}{|l|}{ Inflorescence } \\
\hline Flowers per verticillaster & 2 to 12 & 2 to 10 & 2 \\
\hline \multicolumn{4}{|l|}{ Floral bract } \\
\hline Shape & Ovate to lanceolate & $\begin{array}{l}\text { Lanceolate to ovate- } \\
\text { lanceolate }\end{array}$ & Lanceolate to ovate-lanceolate \\
\hline Size $(\mathrm{mm})$ & $(2.7-) 3-3.8(-5) \times 1.5-2.1$ & $1.9 \times 0.8$ & $(1.7-) 2-2.5 \times 0.5-1$ \\
\hline \multicolumn{4}{|l|}{ Pedicel } \\
\hline Length (mm) & $2-2.1$ & $2-3$ & $1-2(-3)$ \\
\hline \multicolumn{4}{|l|}{ Calyx } \\
\hline Length (mm) & $4.5-6$ & $5-6$ & $3-5$ \\
\hline \multicolumn{4}{|l|}{ Corolla } \\
\hline Color & $\begin{array}{l}\text { Sky blue with white macules } \\
\text { at the throat }\end{array}$ & $\begin{array}{l}\text { Sky blue with white macules } \\
\text { at the throat }\end{array}$ & $\begin{array}{l}\text { Sky blue with white macules at } \\
\text { the throat }\end{array}$ \\
\hline Tube length (mm) & $4-5$ & $4.5-6$ & $(3-) 5-6$ \\
\hline Upper lip length (mm) & $2-2.9$ & $3-3.1$ & $(3-) 4-5$ \\
\hline Lower lip length (mm) & $6-10$ & $5.5-8$ & $4-5$ \\
\hline \multicolumn{4}{|l|}{ Androecium } \\
\hline Filament length (mm) & $0.8-1.5$ & $2-2.5$ & $1-1.5$ \\
\hline Connective length (mm) & $1.9-2.5$ & $1.5-3.6$ & $1.8-2.5$ \\
\hline Theca length (mm) & 1.5 & $1.2-1.4$ & $(0.7-) 1-1.3$ \\
\hline \multicolumn{4}{|l|}{ Gynoecium } \\
\hline Style length (mm) & $5.2-7$ & 6.5 & $7-8$ \\
\hline Style pubescence & Glabrous & Glabrous & Pilose \\
\hline \multicolumn{4}{|l|}{ Nutlet } \\
\hline Length (mm) & $1.6-2 \times 1.4-1.6$ & $1.2-1.8 \times 0.9$ & $1.5-2 \times 1-1.3$ \\
\hline Vegetation & Pine-oak forests & Oak forest & $\begin{array}{l}\text { Tropical deciduous and ecotones } \\
\text { with pine-oak and oak forests }\end{array}$ \\
\hline Geographical range & $\begin{array}{l}\text { Sinaloa, Durango and } \\
\text { Northern Jalisco }\end{array}$ & Western Jalisco & Western Jalisco \\
\hline Altitudinal range $(\mathrm{m})$ & $2230-2533$ & $1500-2500$ & $600-1640$ \\
\hline
\end{tabular}




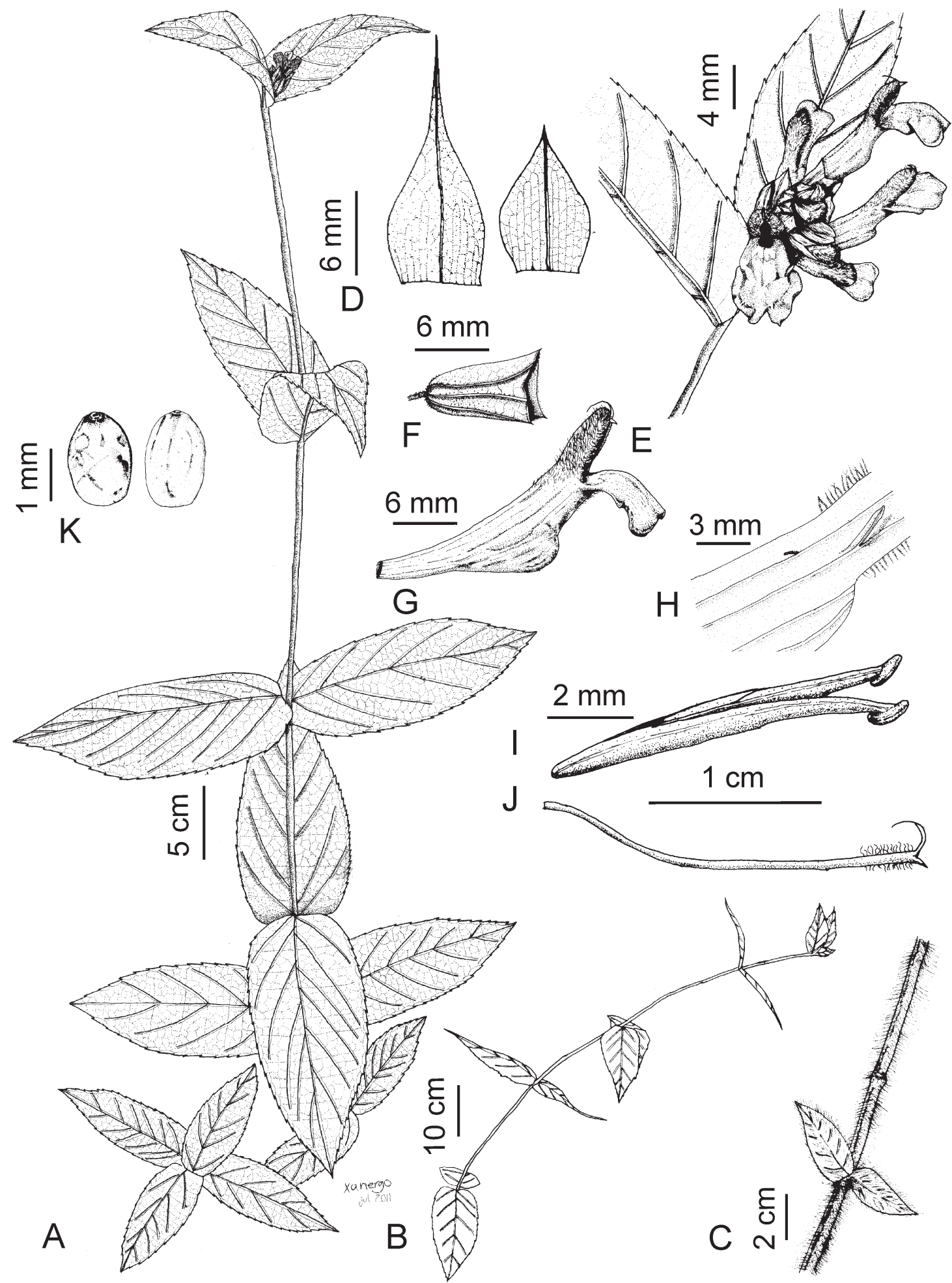

Figure 1. Salvia carreyesii J. G. González. A, general aspect, upper view; B, general aspect lateral view; C, fragment of a young stem; D, floral bracts; E, inflorescence; F, calyx; G, corolla; H, corolla dissection showing the filament toward the throat and minute staminodes behind; I, connectives and thecae; J, style; K, nutlets. (Drawn from the holotype and living plants at botanical garden del Instituto de Botánica, Universidad de Guadalajara). 


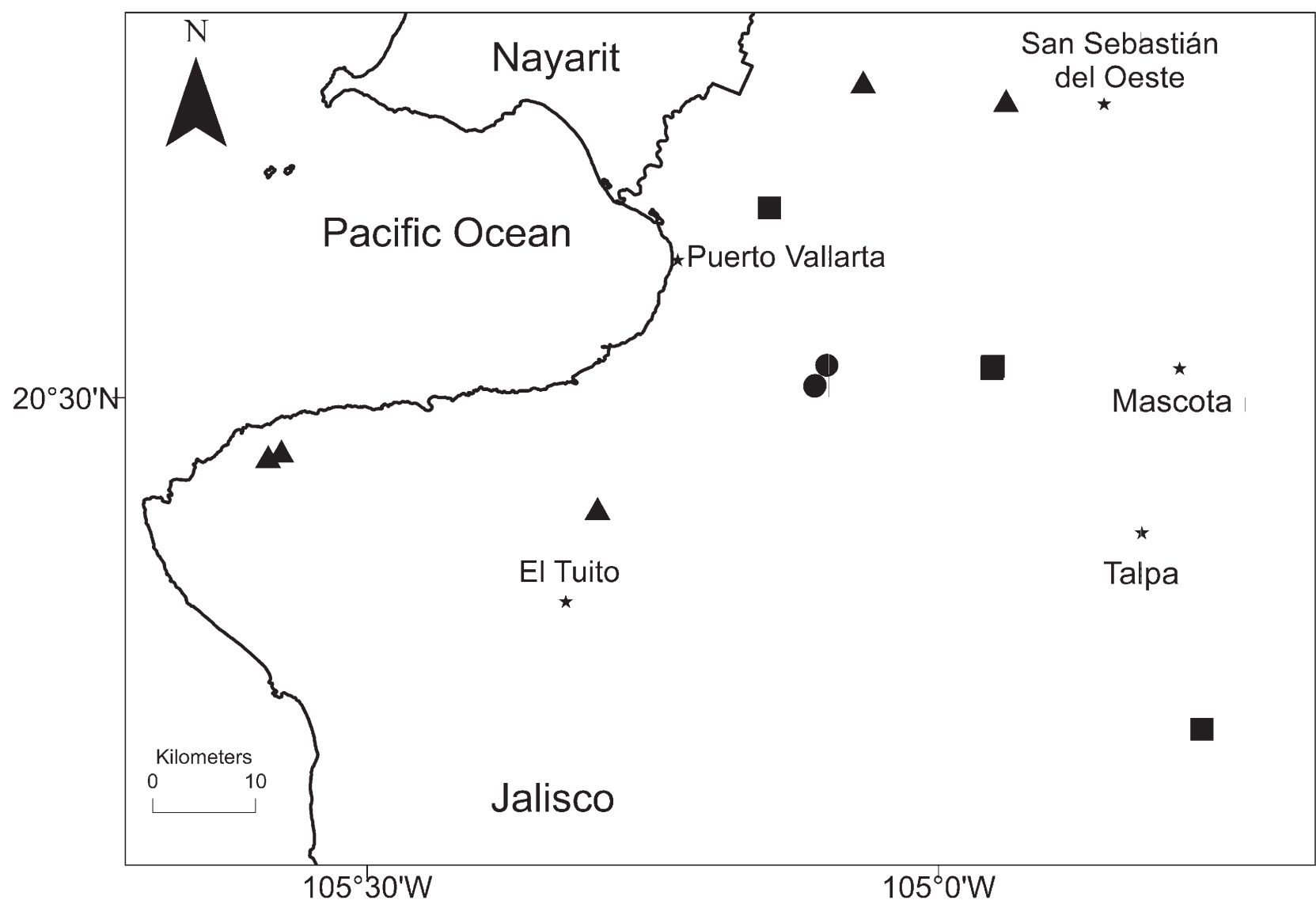

Figure 2. Distribution of the 3 new species: Salvia carreyesii J. G. González (dots); S. ibugana J. G. González (triangles), and S. ramirezii J. G. González (squares).

verticillasters 2 to 8 -flowered, and 6-8 $\mathrm{mm}$ long calyces (Table 3).

The new taxon represents an interesting extension of the altitudinal and vegetational distribution of the species of section Sigmoideae. None of the 11 species recognized by Espejo and Ramamoorthy (1993) grows under $1000 \mathrm{~m}$ and in tropical subdeciduous forest as $S$. ramirezii does.
The populations of this species from the municipality of Puerto Vallarta tend to exhibit lanceolate and longer leaves (up to $23 \mathrm{~mm}$ long), while the populations from Cabo Corrientes and Mascota have triangular and shorter leaves (up to $13 \mathrm{~mm}$ long). However, the variation in these characters between the populations is not discontinuous, so they cannot be clearly separated as to establish infraspecific taxa.

Key for Salvia ramirezii and allies

1a. Leaf blades cuneate at the base

S. quercetorum

$1 \mathrm{~b}$. Leaf blades rounded or slightly cordate at the base

2a. Petioles 0-3.8 mm long; leaf blades triangular, triangular-lanceolate to lanceolate, up to $2.3 \times 1.33 \mathrm{~cm}$, glabrous, margin entire or sparsely crenate; verticillasters 2-flowered; lower corolla lips $4-5 \mathrm{~mm}$ long, style pilose........S. ramirezii 2b. Petioles (2-)16-23 mm long; leaf blades ovate to rhombic-deltoid, up to $4.56 \mathrm{~cm} \times 3.5 \mathrm{~cm}$, pubescent, margin serrate; verticillasters 2 to 6-flowered; lower corolla lips 6-10 mm long, style glabrous. 


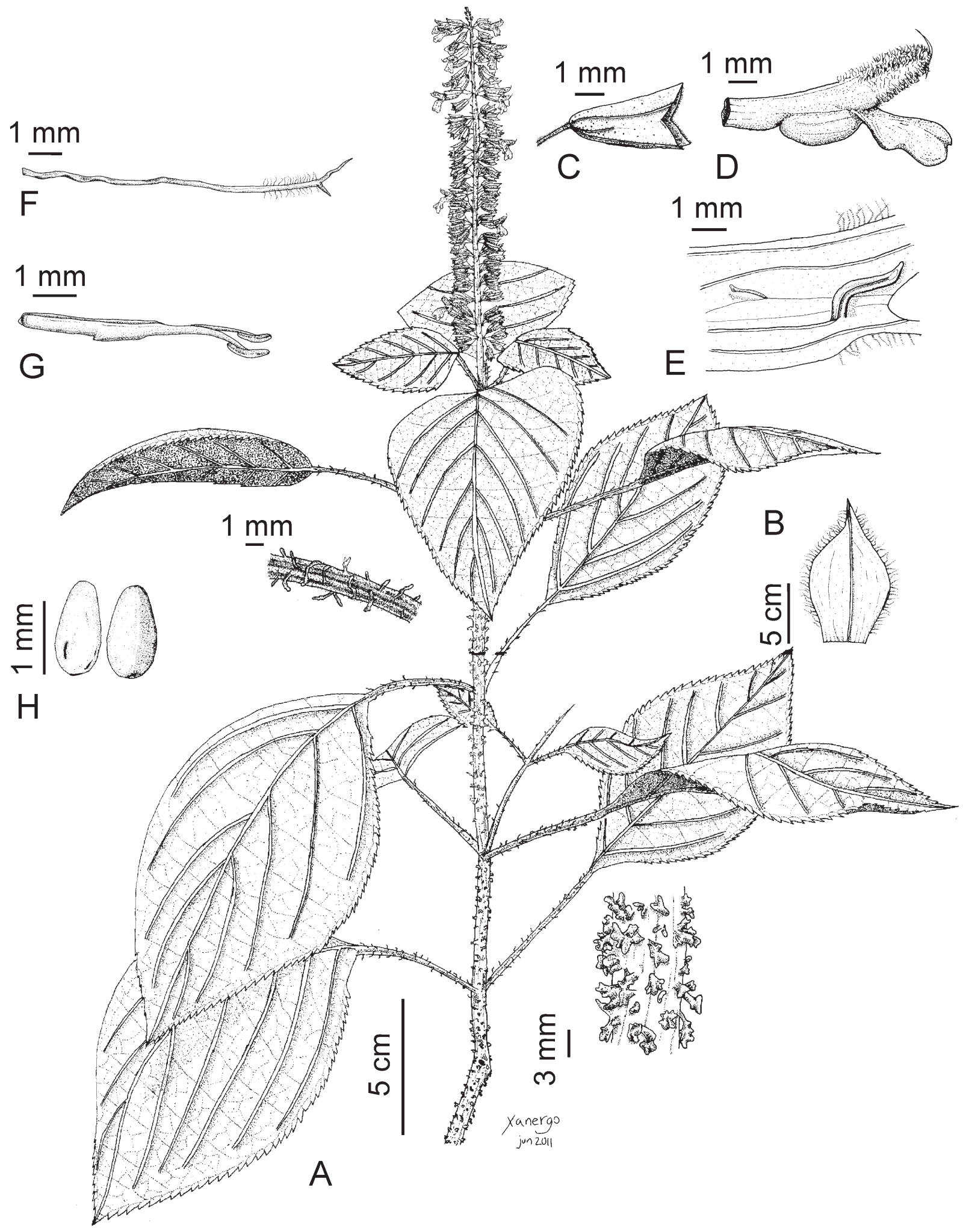

Figure 3. Salvia ibugana J. G. González. A, general aspect with petiole and stem showing the digitiform or lichenoid papillae; B, floral bract; C, calyx; D, corolla; E, corolla dissection showing the filament toward the throat and staminode above and behind the insertion point of the filament to the corolla tube; F, style; G, connectives and thecae; H, nutlets (drawn from the holotype). 


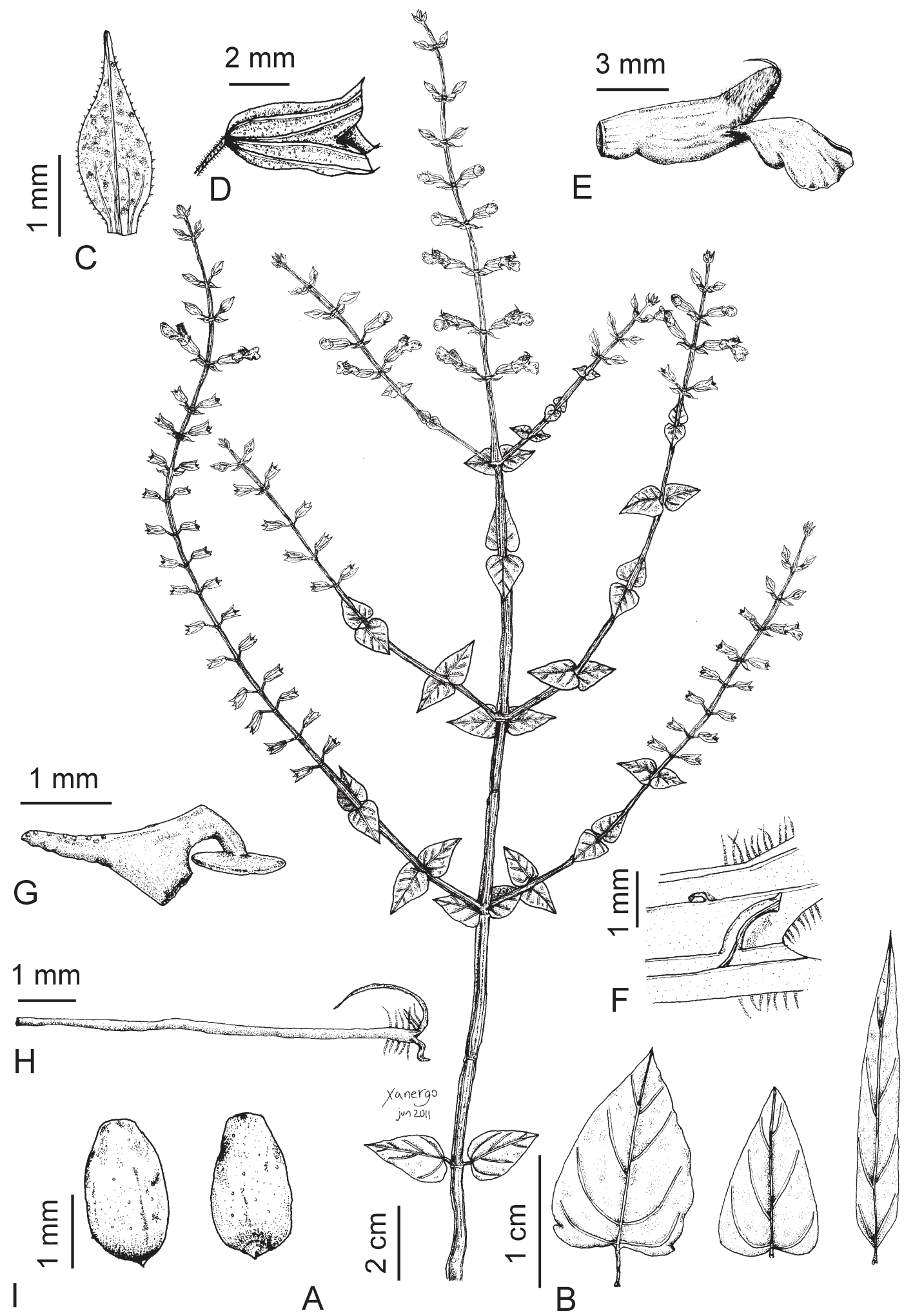

Figure 4. Salvia ramirezii J. G. González. A, general aspect; B, leaves; C, floral bract; D, calyx; E, corolla; F, corolla dissection showing the filament toward the throat and the staminode above and behind the insertion point of the filament to the corolla tube; G, stamen; H, style; I, nutlets (drawn from the holotype and Ramirez et al. 5212). 


\section{Acknowledgments}

We thank the curators and colleagues from the herbaria consulted: IBUG, IEB, MEXU, and XAL, for the help and facilities provided in reviewing their collections. We thank Pablo Carrillo Reyes from the Instituto de Ecología (Centro Regional del Bajío), who kindly notified us about the interesting specimen he collected in Puerto Vallarta, and provided us his specimens. Ricardo Guerrero Hernández, Ernesto De Castro and Arturo Castro Castro contributed in the field work. We thank Robin Middleton and Ernesto De Castro for reviewing the writing and spelling of the document. Servando Carvajal Hernández (Instituto de Botánica, Universidad de Guadalajara) checked the latin diagnoses. B. B. Klitgaard (Royal Botanic Gardens, Kew) and two anonymous reviewers substantially improved the paper with their suggestions. Financial support was provided by CONACYT (Consejo Nacional de Ciencia y Tecnología) and Universidad de Guadalajara, Mexico.

\section{Literature cited}

Epling, C. 1939. A revision of Salvia subgenus Calosphace. Feddes Repertorium Specierum Novarum Regni Vegetabilis, Beiheft 110:1-383.

Epling, C. 1940. Supplementary notes on American Labiatae. Bulletin of the Torrey Botanical Club 67:509-534.

Epling, C. 1941. Supplementary notes on American Labiatae-II. Bulletin of the Torrey Botanical Club 68:552-568.

Epling, C. 1944. Supplementary notes on American Labiatae-III. Bulletin of the Torrey Botanical Club 71:484-497.

Epling, C. 1947. Supplementary notes on American Labiatae-IV. Bulletin of the Torrey Botanical Club 74:512-518.

Epling, C. 1951. Supplementary notes on American Labiatae-V. Brittonia 7:129-142.

Epling, C. 1960. Supplementary notes on American LabiataeVII. Brittonia 12:140-150.

Epling, C. and C. Játiva. 1963. Supplementary notes on American Labiatae-VIII. Brittonia 15:366-376.

Epling, C. andC. Játiva. 1966. Supplementary notes on American Labiatae-IX. Brittonia 18:255-265.

Epling, C. andC. Játiva.1968. Supplementary notes on American Labiatae-X. Brittonia 20:295-313.

Epling, C. and M. E. Mathias.1957. Supplementary notes on American Labiatae-VI. Brittonia 8:297-313.

Espejo, S. A. and T. P. Ramamoorthy. 1993. Revisión taxonómica de Salvia sección Sigmoideae (Lamiaceae). Acta Botanica Mexicana 23:65-102. 